\title{
How Foreign Firms Achieve Competitive Advantage in the Chinese Emerging Economy: Managerial Ties and Market Orientation
}

\author{
Julie Juan Li, City University of Hong Kong \\ Kevin Zheng Zhou, The University of Hong Kong \\ Journal of Business Research, 2010, v. 63(8) p. 856-862
}

The authors thank the two anonymous reviewers and Associate Editor, Prof. Hans Mühlbacher, for their insightful and constructive comments on earlier versions. This study was supported by the General Research Fund from the Research Grants Council, Hong Kong SAR Government (Project no. 9041409).

Corresponding author: Julie Li, Department of Marketing, City University of Hong Kong, Kowloon Tong, Hong Kong, Tel: (852) 2964 - 5795, Fax: (852) 2788 - 9146 (julieli@,cityu.edu.hk).

Kevin Zheng Zhou, School of Business, The University of Hong Kong, Pokfulam, Hong Kong, Tel: (852) 2859-1011, Fax: (852) 2858-5614 ( kevinzhou@business.hku.hk). 


\title{
How Foreign Firms Achieve Competitive Advantage in the Chinese Emerging Economy: Managerial Ties and Market Orientation
}

\begin{abstract}
As China experience unprecedented changes in its social, legal, and economic institutions, on what should foreign firms focus more to overcome this challenge, managerial ties or market orientation? This study investigates how managerial ties and market orientation affect competitive advantage and, consequently, firm performance in China. On the basis of a survey of 179 foreign firms in China, we find that both managerial ties and market orientation can lead to firm success--but in different ways. Market orientation enhances firm performance by providing differentiation and cost advantages, whereas managerial ties improve performance through an institutional advantage (i.e., superiority in securing scarce resources and institutional support). Institutional advantage, in turn, leads to differentiation and cost advantages and consequently superior performance.
\end{abstract}

Keywords: managerial ties, market orientation, competitive advantage, institutional advantage, emerging economy 


\section{How Foreign Firms Achieve Competitive Advantage in the Chinese Emerging Economy: Managerial Ties and Market Orientation}

\section{Introduction}

In recent years, foreign investment has poured into China, in the form of either joint ventures or wholly owned subsidiaries, with an attempt to grab the huge potential of the world's fastest-growing markets. China, for example, has been rated the most attractive FDI destination for seven consecutive years by the world's leading executives since 2002 (FDI Confidence Index Survey, 2008). However, despite the attractiveness of the Chinese market, the unprecedented changes that occur in its social, legal, and economic institutions raise serious strategic challenges for foreign enterprises (Li, Zhou, Lam, and Tse, 2006; Zhou and Li, 2007). Intrigued by these challenges, researchers have demonstrated great interest in strategic issues facing firms operating in China. Two primary types of strategic choices seem to have emerged. The first relates to managerial ties and focuses on network-based strategies that use extensive social ties, based on personal trust and relations, to achieve business success (Li , 2008; Peng and Luo, 2000). The second deals with market-based strategies such as market orientation, which promote the importance of delivering superior customer value through quality products to achieve competitive advantage (Zhou, Tse, and Li, 2006; Zhou, Li, Zhou, and Su, 2008).

Despite the growing interest in this strategic issue, researchers continue to debate which strategy is more appropriate for emerging economies (Peng, 2003: 283). Some believe that managerial ties are more fitting because formal, market-supporting institutions are always difficult to develop in emerging economies, especially the legal systems that support the use of contracts (North, 2005). Because of this institutional void, managers often must rely more on their ties with the business community and/or government officials to conduct business and 
coordinate exchanges (Li, Poppo, and Zhou, 2008; Peng and Luo, 2000). In contrast, other researchers have posited that as the construction of formal market institutions progresses, the role of managerial ties necessarily declines (Peng, 2003) and that a market orientation leads to better performance, as evidenced by the many state-owned enterprises that are losing ground to private, mainly market-driven sectors (Zhou et al., 2006). According to this perspective, the ultimate success of any business lies with its ability to serve its customers, which means that as China moves towards a market economy, firms should adopt more market-based strategies, such as market orientation, to improve performance.

Although this debate is highly significant, no study has examined the effects of managerial ties and market orientation simultaneously, leaving this question of strategic choice largely unexplored. Moreover, though both theoretical work and empirical evidence suggest that managerial ties matter in emerging economies, extant research has examined only the direct effects of managerial ties on outcome variables (Batjargal and Liu, 2004). This limited approach leaves "the harder and more interesting issues of how they [ties and networks] matter" largely unanswered (Peng and Luo, 2000: 486). In other words, what are the underlying processes by which managerial ties affect performance?

To address these research gaps, we develop a model (see Figure 1) from the resourcebased view (RBV) that examines how managerial ties and market orientation affect competitive advantage and consequently firm performance. We suggest that in China, an important dimension of competitive advantage lies in a firm's superiority in securing scarce resources and institutional support, which we refer to as "institutional advantage.” For example, Li (2005) suggests that access to land, capital, and human resources is critical to business success in China. Luo (2007) indicates that support from local government is important because the legal system is 
not reliable and subject to particularism and personal accommodation. We argue that both managerial ties and market orientation can lead to firm success but that they accomplish this goal in different ways: Managerial ties foster firm performance through an institutional advantage, whereas market orientation enhances performance by achieving differentiation and cost advantages. Overall, our efforts aim to shed some light on how to overcome deleterious institutional challenges and achieve competitive advantage in the Chinese emerging economy.

Figure 1 here.

\section{Conceptual development}

\subsection{The RBV Framework}

According to the RBV, a firm's competitive advantage stems from its unique assets and distinctive capabilities (Barney, 1991). However, a firm's unique resources do not automatically translate into superior performance; rather, unique resources lead to market-positional superiority which then lead to superior performance (Barney, 1991; Zhou et al., 2008). Competitive advantage literature commonly points to two types of positional superiority: differentiation and cost (Porter, 1985). Cost advantage, or cost leadership, arises when the firm operates at a lower cost than its competitors but offers a comparable product. The primary cost drivers include economies of scale, capacity utilization, and process management, etc. Differentiation advantage is achieved when customers consistently perceive a firm's offerings as superior to those of its competitors. A firm can differentiate itself in various ways, such as providing superior service, offering innovative features, developing a strong brand name, launching effective promotion, and so on.

\subsection{Institutional Advantage}

Although extant literature has mainly focused on differentiation and cost advantages, recent research suggests that in emerging economies, competitive advantage often arises from 
nonmarket, institutional connections (Guillen, 2000; Peng et al., 2005), which we refer to as institutional advantage. A review of this literature suggests that institutional advantage offers essentially two benefits: superiority in obtaining scarce resources and superiority in gaining support from dominant institutions.

First, as the Chinese market is characterized by underdeveloped capital markets, a scarcity of skilled labor, and a lack of reliable market information (Li et al., 2008), business success rests critically in a firm's ability to secure scarce resources. Guillen (2000), for example, finds that close ties within business groups enable firms to gain a resource advantage including securing technology and know-how, arranging financial packages, obtaining land and establishing plants, hiring and training workers, and so forth. With this advantage, business groups excel in repeatedly entering a variety of industries, which is difficult for new entrants to duplicate or overcome (Li, 2005). Second, because market-supporting institutions such as legal systems and stable political structures are particularly difficult to develop in emerging economies (North, 2005), support from dominant institutions is critical for business success. For example, the Chinese government still plays a highly significant role in shaping, and even interfering in, economic actions through its initiation of new regulations and policies, grants of special permits, and imposition of various restrictions (Luo, 2007). Therefore, institutional support represents political capital that helps build a firm's public reputation, social legitimacy, and political effectiveness and that the firm can use to seize potential opportunities or counteract threats (Peng et al., 2005). In summary, institutional advantage offers a firm both tangible (i.e., securing resources) and intangible (i.e., support from dominant institutions) benefits.

\subsection{Managerial Ties as a Source of Advantage}


Managerial ties refer to “executives' boundary-spanning activities and their associated interactions with external entities" (Geletkanycz and Hambrick, 1997: 654). Because economic actions are deeply embedded in networks of interpersonal relations, ties are important means for coordinating exchanges (Granovetter, 1985). Managers can use the social capital inherent in managerial ties to influence the allocation of resources and shape economic actions (Batjargal \& Liu, 2004). The economic transitions make the role of ties more evident. In China, formal institutional constraints, such as laws and regulations, tend to be weak, so firms must rely on informal means such as interpersonal ties to facilitate economic exchanges (Li et al., 2008). In other words, managerial ties substitute for reliable government and the established rule of law (Xin and Pearce, 1996). Empirical studies further find that ties with government officials, as well as with top managers at other firms, positively affect firm performance (Peng and Luo, 2000).

As boundary spanners, managers function through their vital ties to the external entities on which their firms depend. In this sense, managers are brokers armed with useful ties and contacts (Geletkanycz and Hambrick, 1997). In China where market mechanisms and marketsupporting institutions often are underdeveloped or underenforced, top managers resort to networking to seek the institutional support that is taken for granted in developed market economies (Li et al., 2008). For example, closer ties with government officials (e.g., political leaders, officials in industry bureaus and regulatory and supporting organizations) help firms achieve more institutional support—such as interpreting regulations, enforcing contracts, settling negotiations, and erecting entry barriers - to counter the threats and uncertainties inherent in a transitional economy (Peng and Luo, 2000). In addition, ties with government officials help firms obtain scarce resources, such as access to capital, land, and human resources. Although market-based mechanisms have been introduced into China, state regulatory regimes still exert 
considerable influence on firms' operations and Chinese local government still retains the power to allocate scarce resources and grant projects (Luo, 2007).

Because foreign firms are unfamiliar with the prevailing social norms and practices in local market, they may suffer from a liability of foreignness, the additional costs of a firm operating in an overseas market that a local firm would not incur (Ramasamy, Goh and Yeung, 2006). Network with local managers at other firms helps overcome this liability. For example, tight linkages with suppliers enable the firm to acquire quality materials and services and timely delivery, which often are not widely available in China; connections with top managers at other firms in the same industry facilitate information exchange, which sometimes can reveal scarce "insider" information (Li et al., 2008). That is, ties with the business community provide opportunities for shared learning, the transfer of inside information, and resource exchange to adapt to the unfamiliar market. In summary, managerial ties with government officials and the business community enable firms to achieve superiority in terms of gaining support and scarce resources.

H1: Managerial ties enhance performance through institutional advantage.

We further argue that institutional advantage leads first to differentiation and cost advantages and then to better performance. First, an institutional advantage enables a firm to secure scarce resources more effectively than its competitors can. Because of the "economics of shortage" of production factors (e.g., materials, capital, labor, information) in many emerging economies (North, 2005), a firm can achieve a differentiation advantage if the scarce resources it acquires are unavailable to others. Even if the resources are available to others, a firm with an institutional advantage can acquire them at a lower cost, which grants the firm a cost advantage. 
Second, because of the weak legal institutions, the interpretation and reinforcement of rules and regulations are subject to local authorities' discretion (Luo, 2007). If a firm can obtain legitimacy, social support, and approbation from the government, it likely builds a unique corporate and brand image. Furthermore, the social capital generated from institutional support signifies the reputation of and goodwill toward a firm, which helps the firm conduct business more efficiently than others in fast transitioning environments in which opportunistic behavior is salient (Peng et al., 2005). Therefore, we predict that

H2: Institutional advantage leads to differentiation and cost advantages.

\subsection{Market Orientation as a Source of Advantage}

Many studies have strongly advocated that firms should adopt a market orientation to achieve competitive advantage. Market orientation places the highest priority on the profitable creation and maintenance of superior customer value (Slater and Narver, 1995). It includes three behavioral components - customer orientation, competitor orientation, and interfunctional coordination - and emphasizes the need for the entire organization to acquire, disseminate, and respond to market intelligence from both buyers and competitors (Zhou et al., 2008).

A customer orientation emphasizes understanding target customers sufficiently to continuously create superior value for them (Narver and Slater, 1990). Because customers' needs change rapidly, a customer orientation requires a clear understanding of both the present and future demand dynamics of target customers. With its external focus on collecting, analyzing, and disseminating information about customers, a customer-oriented firm can anticipate its customers' changing needs and respond to them through continuous innovation (Zhou, Brown, and Dev, 2009). With the knowledge of what customers desire, a customeroriented firm can make its market offerings more appealing by adjusting its marketing mix. 
Because customer orientation aims to achieve long-term customer satisfaction, the firm is highly motivated to provide offerings that uniquely meet the particular needs of its target market (Day, 1994).

A competitor orientation focuses on watching competitors closely, matching the marketing initiatives of competitors quickly, and understanding both the short-term strengths and weaknesses and the long-term capabilities and strategies of current and potential competitors (Narver and Slater, 1990). Because its emphasis is to "meet and beat the competition," a competitor orientation enables a firm to compare its capacities and offerings with those of its competitors. After scrutinizing its value chain compared with that of its competitors, the firm can identify possible ways to streamline and reduce costs (Porter, 1985). Moreover, with a clear understanding of its own and its competitors' strengths and weaknesses, the firm may choose to pursue a unique, untapped position and achieve a differentiation advantage (Day, 1994).

Finally, interfunctional coordination focuses on the dissemination and use of market information through coordinated efforts across the whole firm and emphasizes the collective use of the organization's resources to deliver superior customer value (Narver and Slater, 1990). The basic idea is that every employee of a company can contribute something of value to customers, so if the firm can coordinate and integrate its financial, human, and other resources, it can provide goods and services that better suit its customers' needs. In addition, by improving cooperation among different departments, interfunctional coordination can lead to greater efficiency and thereby decrease production and administration costs (Jaworski and Kohli, 1993).

In summary, with its three behavioral components (customer orientation, competitor orientation, and interfunctional coordination), a market orientation enables the firm to respond to 
market intelligence in a timely and efficient manner and deliver superior value to meet the unique needs of its market. Thus, it is a source of cost and differentiation competitive advantages.

H3: Market orientation enhances performance through differentiation and cost advantages.

Because our literature review suggests no evidence that links a market orientation with institutional advantage, we do not formalize such a hypothesis. Instead, we explore this possibility in our empirical analysis.

\section{Method}

\subsection{Sampling and Data Collection}

To test the hypotheses, we examined foreign-invested enterprises (FIEs) in manufacturing sectors located in three major areas (Beijing, Guangzhou, and Shanghai) in China. On the one hand, managerial ties are deeply embedded in Chinese history and have been referred to as the lifeblood of business conduct in China (Li et al., 2008). On the other hand, the influx of foreign firms has created new forms of competition, marketing, and management that make market orientation more important for businesses to compete in this market (Zhou et al., 2005). Our research context thus provides a rich setting to test the role of ties and market orientation.

We first developed an English-language version of the questionnaire. To ensure conceptual equivalence, it was translated into Chinese and then back-translated twice by independent translators. Any conflicts were discussed by the researchers and translators until we had reached an agreement. To ensure the content and face validity of the measures, we conducted five in-depth interviews with senior marketing managers, during which we asked them to verify the relevance and completeness of the questionnaire items. On the basis of their responses, we revised a few questionnaire items to enhance their clarity. We then conducted a 
pilot study with 20 senior managers with titles such as CEO, vice president, senior marketing director, and general manager. We asked these respondents not only to answer all the questionnaire items but also to provide feedback about their design and wording. The results of this pilot survey revealed that all the items were well understood by the respondents and that most had a reasonably diverse range of responses. On the basis of the pilot test, we refined the questionnaire and finalized the survey.

We selected a random sample of 600 FIEs from a list of manufacturing firms with fourdigit standard industrial classification codes 2011-3899 located in Beijing, Guangzhou, and Shanghai. These firms spanned diverse industries such as electronics, computer equipment, chemicals, apparel, furniture, and plastics. In each firm, a senior manager (e.g., CEO, vice president, senior marketing manager) served as the key informant; our field interviews revealed that these managers were familiar with their firm's strategic orientations, ties and networking, and competitive advantages. We recruited trained interviewers to conduct onsite personal survey, which is more likely to generate valid information in emerging economies (Bao, Zhou, and Zhou, 2006; Li et al., 2008).

To establish the causal link of the model and reduce the common method bias, we undertook a two-stage design. In Stage 1 (February/March 2004), we collected information on managerial ties and market orientation. Senior managers were first contacted via telephone by trained interviewers to solicit their cooperation. The respondents were informed of the confidentiality of their responses and the academic purpose of the project and were promised a reward of a summary report of the survey and a souvenir. Through these initial telephone contacts, 228 senior managers orally agreed to participate. Then, 188 were successfully interviewed onsite, representing a response rate of $31.1 \%$. A comparison between responding 
and nonresponding firms indicates no significant differences in terms of the key firm characteristics (i.e., firm ownership, size, location, and industry), so nonresponse bias is not a major concern in our study.

Stage 2 occurred one year later (early 2005), when we collected information on competitive advantage from senior managers through telephone interview. Whenever possible, we contacted the same senior manager who had responded to the Stage 1 survey to obtain such information; we successfully did so in 149 cases. In the remaining 39 cases, the manager either was unavailable or had left the company, so we tried to contact another senior manager with an equivalent position to provide the information and successfully did so in 30 cases. Therefore, the final sample comprises 179 FIEs. The test-retest reliability of the responses in 2004 and 2005 is $.85(\mathrm{p}<.001)$ for differentiation advantage and $.78(\mathrm{p}<.001)$ for cost advantage. These highly consistent results demonstrate the validity of our key informant approach. Finally, we obtained return on asset (ROA) information from archival data to indicate firm performance.

Of the 179 FIEs, the majority (63.2\%) had between 100 and 1,000 employees, and 78.7\% had annual sales revenues of more than US\$3 million. Furthermore, $48.6 \%$ were joint ventures, and $51.4 \%$ were wholly foreign-owned firms. In terms of industry, $48.0 \%$ were high-tech companies, such as computer equipment, electronics, and biotech, whereas $52.0 \%$ were others, such as transportation equipment, apparel, furniture, and plastics. On average, the respondents had been working for 9.5 years in the industry and 4.8 years with their company.

\subsection{Measures}

In the Appendix, we provide the measurement items and their validity assessments. To measure managerial ties, we adopted the six-item measure from Peng and Luo (2000). We used Narver and Slater's (1990) 15-item scale to measure market orientation. To measure 
differentiation advantage, we developed a four-item measure based on Porter (1985) and Song and Perry (1997). For cost advantage, we used scales from Narver and Slater (1990) and Porter (1985). We newly developed the measure of institutional advantage. Consistent with our conceptualization, we first drafted a set of ten items pertaining to a firm's superiority in acquiring scarce resources and institutional support. Then, on the basis of our in-depth interviews with five senior managers, we modified the measures and reduced the number of items to six. We then dropped two items on the basis of our pretest with 20 senior managers and thereby obtained a four-item scale to measure institutional advantage. We used ROA to indicate firm performance and obtained the information from archival data.

Construct validity. We ran confirmatory model analysis to estimate the construct validity (see the Appendix). The model provides satisfactory fit for the data (goodness-of-fit index [GFI] $=.90$, comparative fit index $[\mathrm{CFI}]=.92$, incremental fit index $[\mathrm{IFI}]=.92)$. Furthermore, all factor loadings were highly significant $(p<.001)$, the composite reliabilities of all constructs (.71-.90) exceeded the .70 benchmark, and all average variances extracted (AVE) were greater than .50. Thus, these measures demonstrate adequate convergent validity and reliability (Fornell and Larker, 1981). To assess the discriminant validity, we calculated the shared variance between all possible pairs of constructs to determine if they were lower than the AVE for the individual constructs. The results show that for each construct, the AVE was much higher than its highest shared variance with the other constructs, providing additional support for the discriminant validity (see the Appendix) (Fornell and Larker, 1981). Overall, these results indicate that our measures possess adequate reliability and validity.

Control variables. To account for the effects of extraneous variables, we include firm size, firm age, firm ownership, industry, and market growth as control variables. We use the 
logarithm of the number of employees as an indicator of firm size. Firm age indicates the number of years the firm has been in operation. Firm ownership provides a dummy variable to control for potential variations between international joint ventures (coded 1) and foreign wholly-owned firms (coded 0). We measured industry as a dummy variable, where $1=$ high-tech (e.g., computer and electronic equipment) and $0=$ otherwise (e.g., apparel, furniture). For market growth, we asked respondents to indicate "the average annual growth rate of total sales in the served market segment over the past three years" $(1=$ very low, $7=$ very high $)($ Narver and Slater, 1990). Table 1 reports the basic descriptive statistics and correlations of the measures.

Table 1 here.

\section{Analyses and Results}

To test the hypotheses, we employ structural equation modeling with the maximum likelihood estimation, using the model illustrated in Figure 1 as the base model. Because our study focuses on the overall effect of managerial ties and market orientation rather than the effects of their components, we treat them as second-order factors with summated first-order indicators. We include the five control variables in the models and link them directly to competitive advantages and performance. To test the mediating role of competitive advantages, we also link market orientation and managerial ties directly to performance. The model fit the data adequately $(\mathrm{GFI}=.90, \mathrm{CFI}=.90, \mathrm{IFI}=.91)($ see Table 2$)$.

\section{Table 2 here.}

H1 and H2 deal with how managerial ties affect performance. As we show in Table 2, managerial ties positively affect institutional advantage $(\beta=.39, p<.001)$ but have no impact on 
differentiation $(\beta=-.03, p>.10)$ or $\operatorname{cost}(\beta=-.20, p>.10)$ advantages, in support of H1. In addition, institutional advantage has a positive effect on differentiation $(\beta=.22, p<.01)$ and cost $(\beta=.36, p<.001)$ advantages, in support of $\mathrm{H} 2$.

Table 2 also shows that neither managerial ties nor institutional advantage has a direct impact on firm performance. According to Baron and Kenny (1986), these results indicate that differentiation and cost advantages fully mediate the relationship between institutional advantage and performance, and institutional advantage fully mediates the relationship between managerial ties and differentiation/cost advantage.

H3 pertains to the underlying process by which marketing orientation affects performance. Market orientation is positively related to differentiation $(\beta=.35, p<.001)$ and $\operatorname{cost}(\beta=.26, p<.01)$ advantages but not associated with institutional advantage $(\beta=-.01, p>$ .10. In addition, both differentiation $(\beta=.26, p<.01)$ and $\operatorname{cost}(\beta=.26, p<.01)$ advantages positively affect performance. Therefore, H3 is fully supported. Because market orientation has no direct impact on performance when differentiation and cost advantages are in the model, differentiation and cost advantages fully mediate the relationship between market orientation and performance (Baron and Kenny, 1986).

Effects of control variables. As we show in Table 2, firm size positively affects institutional advantage, suggesting that large firms are more likely to gain resource superiority and institutional support. However, firm size also is negatively associated with firm performance, highlighting the potential liability of large firms. In addition, a fast-growing market is beneficial for firms to achieve superior performance.

\section{Discussion}

\subsection{Contributions}


Our study contributes to the literature in the following ways. First, our study adds to the competitive advantage literature by empirically validating the construct of institutional advantage, which we believe is a significant dimension of competitive advantage in emerging economies (cf. Peng et al., 2005). Due to the shortage of production factors and efficient institutional structures, business success in China relies critically on a firm's ability to secure scarce resources and gain support from dominant institutions. Our findings indicate the significance of institutional advantage for boosting firm performance even for foreign firms in China. We also find that institutional advantage does not lead directly to superior performance; instead, it first leads to differentiation and cost advantages that consequently enhance performance. This two-step process explains how institutional advantage is beneficial to firm success: It helps a firm obtain a unique position and gain a cost leadership. These findings enrich the existing theory by identifying a new concept —institutional advantage — into studies of emerging economies (cf. Burgess and Steenkamp, 2006).

Second, our research fills an important research gap by examining the process by which managerial ties affect performance (Batjargal and Liu, 2004). Recent empirical studies have found that managerial ties positively affect organizational performance in China (Peng and Luo, 2000), and our findings illustrate the underlying reason: Managerial ties help firms achieve an institutional advantage, which in turn enhances differentiation and cost advantages and consequently firm performance. These results tackle the "harder and more interesting" issues of how managerial ties matter (Peng and Luo, 2000).

Third, our findings provide some insights into the roles of managerial ties and market orientation in emerging economies. Previous research has found that market orientation fosters performance in emerging economies such as China (Zhou et al., 2005) and Central Europe (Hooley 
et al., 2000). Our findings show that both market orientation and managerial ties can lead to firm success, but they accomplish that success in different ways. The former affects performance through differentiation and cost advantages, whereas the latter leads to an institutional advantage, which in turn benefits performance through differentiation and cost advantages. Overall, these results suggest that managerial ties enable a firm to overcome potential disadvantages in institutional environments, but the ultimate success lies in the firm's ability to achieve differentiation and cost advantages.

So on which strategy should foreign firms focus more in emerging economies, managerial ties or market orientation? Our findings suggest that both strategies can enable a firm to achieve better performance. More important, managers should clearly understand what type of advantage stems from managerial ties and market orientation. To obtain a differentiation or cost advantage, a market orientation is more desirable. That is, the firm should pay close attention to its customers, monitor its competitors constantly, and coordinate its functional units better. To achieve an institutional advantage, the key path is to cultivate close ties with government officials and managers at other firms. However, institutional advantage itself does not lead directly to superior performance; ultimate success still rests on the ability of institutional advantage to effect differentiation and cost advantages, which foster superior performance. Therefore, firms should be cautious in following the common wisdom that "who you know matters most" when doing business in emerging economies. Instead, firms must carefully identify the competitive advantage they desire and choose their strategy accordingly.

\subsection{Limitations and Future Research}

Our findings must be interpreted within the limitations of this study. First, our sample consists of foreign manufacturing firms in more developed areas in China. Therefore, samples 
from less developed areas are needed to generalize the findings and, more important, test whether the roles of market orientation and managerial ties vary across less and more developed areas. Similarly, future research can extend our model to non-emerging, more developed economies, and compare the role of managerial ties in emerging versus developed economies. Second, though our research adopts a two-stage (2004/2005) data collection method, a longitudinal study is needed to examine the intriguing issue of how the roles of market- and network-based strategies change over time. Related, this study does not investigate the institutional conditions in which market orientation or managerial ties are more or less effective. A challenge for additional research is to identify those institutional characteristics that are associated with a greater or lesser degree of effectiveness of market orientation and managerial ties in emerging economies. Third, our study focuses on competitive advantage as an intermediate variable. Additional research should develop a more fully specified model that includes action components—-such as organization learning, organizational structure (e.g., formalization, centralization, reward system), and organizational behavior (e.g., interdepartmental conflict, connectedness)— to uncover the relationships between market orientation/managerial ties and competitive advantage more fully. Incorporating these variables will enrich our understanding of why and how these strategic choices matter. 


\section{REFERENCES}

Bao Y, Zhou KZ, Zhou N. Social Alienation in a Transitional Economy: Antecedents and Impact on Attitude toward Social Reform. J Bus Res 2006;59(9): 990-998.

Barney JB. Firm resources and sustained competitive advantage. J Manage 2001;17(1): 99-120.

Baron RM, Kenny DA. The moderator-mediator variable distinction in social psychological research: Conceptual, strategic and statistical considerations. J Personality and Social Psychology 1986;51(6): 1173-1182.

Batjargal B, Liu M. Entrepreneurs' access to private equity in China: The role of social capital. Org Sci 2004;15: 159-172.

Burgess SM, Steenkamp JB. Marketing renaissance: How research in emerging markets advances marketing science and practice. Inter J Res in Mark 2006;23: 337-356.

Day GS. The capabilities of market-driven organizations. J Mark 1994;58(4): 37-52.

FDI Confidence Index Survey (2008) Global Business Policy Council. A.T. Kearney, Inc. http://www.atkearney.com/.

Fornell C, Larker DF. Evaluating structural equation models with unobservable variables and measurement error. J Mark Res 1981;18: 39-50.

Geletkanycz MA, Hambrick DC. The external ties of top executives: Implications for strategic choices and performance. Admin Sci Qua 1997;42: 654-681.

Granovetter M. Economic action and social structure: A theory of embeddedness. Amer J Socio 1985;91: 481-510.

Guillen M F. Business groups in emerging economies: A resource-based view. Acad Manage J 2000;43(3): 362-380. 
Hooley G, Cox T, Fahy J, Shipley D, Beracs J, Fonfara K, Snoj B. Market orientation in the transition economies of Central Europe: Tests of the Narver and Slater market orientation scales. J Bus Res 2000;50(3): 273-285.

Jaworski BJ, Kohli AK. 'Market orientation: Antecedents and consequences. J Mark 1993;57: $53-70$.

Li JJ. The formation of managerial networks of foreign firms in China: The effects of strategic orientations. Asia Paci J Manage 2005;22: 423-443.

Li JJ. How to retain local senior managers in international joint ventures: The effects of alliance relationship characteristics. J Bus Res 2008;61(9): 986-994

Li JJ, Poppo L, Zhou KZ. Do managerial ties in China always produce value? Competition, uncertainty, and domestic vs. foreign firms. Strateg Manage J 2008;29(4): 383-400.

Li JJ, Zhou KZ, Lam S, Tse DK. Active Trust Building of Local Senior Managers in International Subsidiaries. J Bus Res 2006;59(1): 73-80.

Luo Y. Are joint venture partners more opportunistic in a more volatile environment?' Strateg Manage J 2007;28: 39-60

Narver JC, Slater SF. The effect of a market orientation on business profitability. J Mark 1990;54 (4): 20-35.

North D. Understanding the Process of Economic Change. Princeton, NJ: Oxford University Press; 2005.

Peng MW. Institutional transitions and strategic choices. Acad Manage Rev 2003;28: 275-296.

Peng MW, Lee SH, Wang DYL. What determines the scope of the firm over time? A focus on institutional relatedness. Acad Manage Rev 2005;30(3): 622-633. 
Peng MW, Luo Y. Managerial ties and firm performance in a transition economy: The nature of a micro-macro link. Acad Manage J 2000;43: 486-501.

Porter ME. Competitive Advantage, The Free Press, New York; 1985

Ramasamy B, Goh KW, Yeung MCH. Is Guanxi (relationship) a bridge to knowledge transfer? J Bus Res 2006;59(1): Pages 130-139.

Slater SF, Narver JC. Market orientation and the learning organization. J Mark 1995;59(3): 6374.

Song MX, Perry ME. A cross-national comparative study of new product development processes: Japan and the United States. J Mark 1997;61(2): 1-18.

Xin K, Pearce JL. Guanxi: Connections as substitutes for formal institutional support. Acad Manage J 1996;39: 1461-1568.

Zhou KZ, Gao GY, Yang Z, Zhou N. Developing strategic orientation in China: Antecedents and consequences of market and innovation orientations. J Bus Res 2005;58(8): 1049-1058.

Zhou KZ, Li CB. How does strategic orientation matter in Chinese firms? Asia Paci J Manage 2007; 24(4): 447-466

Zhou KZ, Li JJ, Zhou N, Su C. Market orientation, job satisfaction, product quality, and firm performance: Evidence from China. Strateg Manage J 2008;29(9): 985-1000.

Zhou KZ, Tse DK, Li JJ. Organizational change in emerging economies: Drivers and consequences. J Inter Busi Stud 2006;37(2): 248-263.

Zhou KZ, Brown JR, Dev CS. Market orientation, competitive advantage, and performance: A demand-based perspective. J Bus Res 2009; advanced online access 
Figure 1. The Conceptual Model

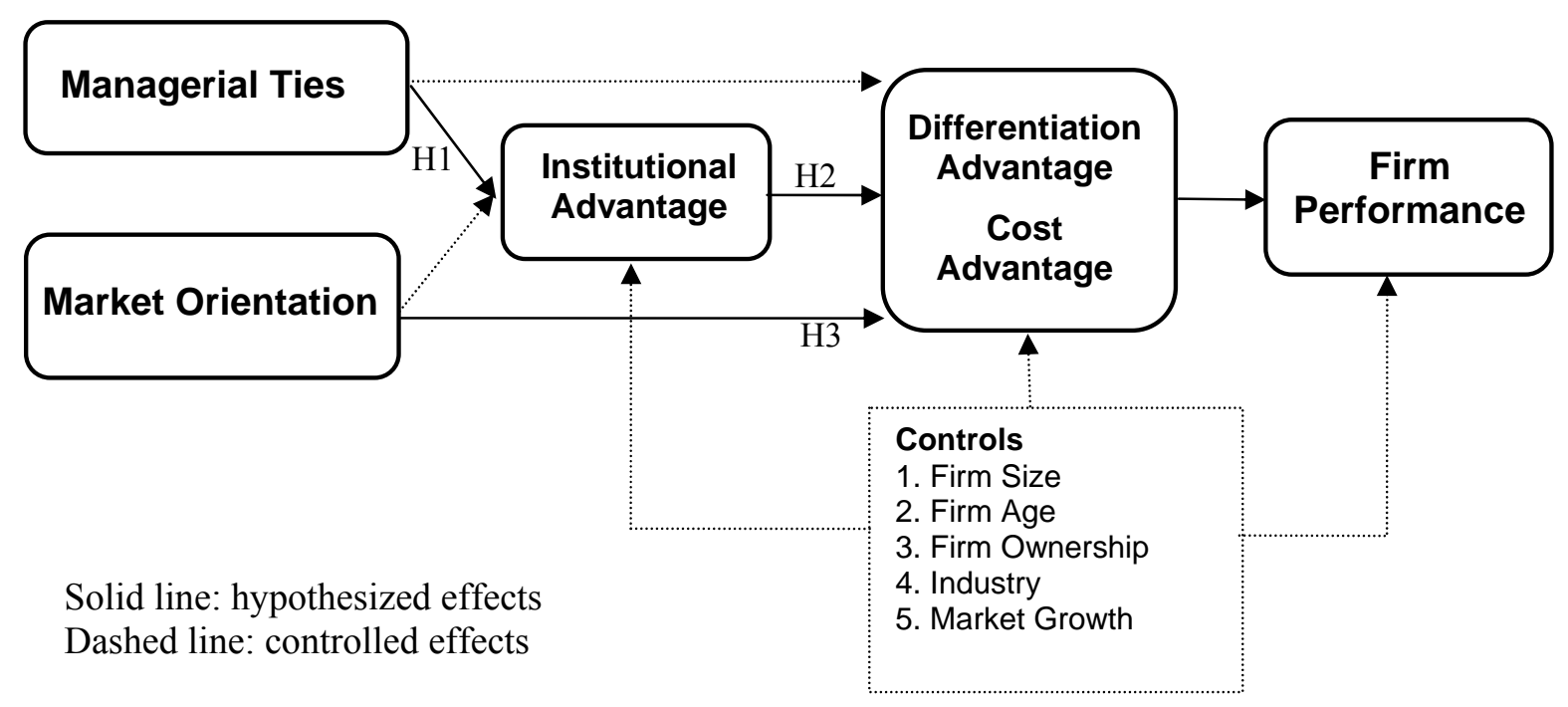


Table 1

Basic Descriptive Statistics of the Constructs

\begin{tabular}{|c|c|c|c|c|c|c|c|c|c|c|c|}
\hline Construct & 1 & 2 & 3 & 4 & 5 & 6 & 7 & 8 & 9 & 10 & 11 \\
\hline 1. Managerial ties & 1.00 & & & & & & & & & & \\
\hline 2. Market orientation & $.36^{* *}$ & 1.00 & & & & & & & & & \\
\hline 3. Differentiation advantage & $.24 * *$ & $.36^{* *}$ & 1.00 & & & & & & & & \\
\hline 4. Cost advantage & $.17 *$ & $.21 * *$ & $.38 * *$ & 1.00 & & & & & & & \\
\hline 5. Institutional advantage & $.34 * *$ & $.22 * *$ & $.37 * *$ & $.32 * *$ & 1.00 & & & & & & \\
\hline 6. ROA & $.14^{*}$ & $.18^{*}$ & $.26 * *$ & $.27 * *$ & $.18^{*}$ & 1.00 & & & & & \\
\hline 7. Firm size & -.07 & -.11 & .10 & .04 & $.20 * *$ & -.10 & 1.00 & & & & \\
\hline 8. Firm age & -.12 & .04 & .05 & -.04 & .06 & -.02 & $.29 * *$ & 1.00 & & & \\
\hline 9. Firm ownership & .11 & -.13 & -.06 & -.10 & .03 & -.01 & .00 & -.04 & 1.00 & & \\
\hline 10. Industry & -.02 & -.10 & .04 & .08 & .03 & -.04 & .01 & $-.16^{*}$ & -.06 & 1.00 & \\
\hline 11. Market growth & $.29 * *$ & $.26 * *$ & $.27 * *$ & $.25 * *$ & $.24 * *$ & $.19 *$ & -.02 & $-.26^{* *}$ & .01 & .13 & 1.00 \\
\hline Mean & 5.29 & 5.57 & 5.15 & 4.50 & 4.89 & .15 & 5.50 & 9.69 & .49 & .48 & 4.98 \\
\hline Standard deviation & .81 & .69 & .92 & .88 & 1.03 & .15 & 1.05 & 14.63 & .50 & .50 & 1.11 \\
\hline
\end{tabular}

Notes: Sample size $=179$.

$* * p<.01, * p<.05$. 
Table 2

Standardized Structural Equation Parameter Estimates (t-value)

\begin{tabular}{lcccc}
\hline $\begin{array}{c}\text { Exogenous } \\
\text { Variables }\end{array}$ & $\begin{array}{c}\text { Institutional } \\
\text { Advantage }\end{array}$ & $\begin{array}{c}\text { Differentiation } \\
\text { Advantage }\end{array}$ & $\begin{array}{c}\text { Cost } \\
\text { Advantage }\end{array}$ & $\begin{array}{c}\text { Firm } \\
\text { Performance }\end{array}$ \\
\hline $\begin{array}{l}\text { Managerial } \\
\text { ties }\end{array}$ & $.39^{* * *}$ & -.03 & -.20 & -.09 \\
Market & $(3.17)$ & $(-.26)$ & $(-1.33)$ & $(-.61)$ \\
orientation & -.01 & $.35^{* * *}$ & $.26^{* *}$ & -.11 \\
Institutional & $(-.05)$ & $(3.21)$ & $(2.33)$ & $(-.90)$ \\
advantage & - & $.22^{* *}$ & $.36^{* * *}$ & -.06 \\
Differentiation & - & $(2.60)$ & $(3.96)$ & $(-.49)$ \\
advantage & - & - & - & $.22^{* *}$ \\
Cost & - & - & $-2.67)$ \\
advantage & & & $-29 *$ & $(2.86)$ \\
\hline Controls & $.19 *$ & .10 & .02 & $-.16^{*}$ \\
Firm size & $(2.39)$ & $(1.29)$ & $(.29)$ & $(-2.09)$ \\
& .11 & .03 & -.07 & .05 \\
Firm age & $(1.40)$ & $.38)$ & $(-.81)$ & $(.58)$ \\
& & & -.08 & .03 \\
Firm & -.01 & -.01 & $(-1.04)$ & $(.41)$ \\
ownership & $(-.12)$ & $(-.19)$ & .03 & -.09 \\
Industry & .07 & .04 & $(.44)$ & $(-1.17)$ \\
Market growth & $(.98)$ & $(1.61)$ & $(1.68)$ & $(1.96)$ \\
\hline
\end{tabular}

Goodness-of-Fit: $\chi^{2}(182)=389, p<.001, \mathrm{GFI}=.90, \mathrm{CFI}=.90, \mathrm{IFI}=.91$; RMSEA $=.05$.

$* * * p<.001, * * p<.01,{ }^{*} p<.05$. 
APPENDIX: Measurement Items and Validity Assessment

Managerial Ties SFL

Ties with government officials: $\mathrm{CR}=.88, \mathrm{AVE}=.70, \mathrm{HSV}=.24$

Top managers at our firm have heavily utilized personal ties, networks, and connections with

1. Political leaders in various levels of the government.

2. Officials in industrial bureaus.

3. Officials in regulatory and supporting organizations such as tax bureaus, state banks, commercial administration bureaus, and the like.

Ties with managers at other firms: $\mathrm{CR}=.71, \mathrm{AVE}=.44, \mathrm{HSV}=.24$

Top managers at our firm have heavily utilized personal ties, networks, and connections with

1. Top managers at buyer firms.

2. Top managers at supplier firms.

3. Top managers at competitor firms.

Market Orientation

Customer orientation: $\mathrm{CR}=.83, \mathrm{AVE}=.51, \mathrm{HSV}=.26$

1. We constantly monitor our level of commitment and orientation to serving customer needs. $\quad .70$

2. Our business strategies are driven by the goal of creating greater customer value.

3. Our strategy for competitive advantage is based on our understanding of customers' needs.

4. Our business objectives are driven primarily by customer satisfaction.

5. We measure customer satisfaction systematically and frequently. $\quad .62$

6. We pay close attention to after-sales service. $\quad .71$

Competitor orientation: $\mathrm{CR}=.76, \mathrm{AVE}=.52, \mathrm{HSV}=.26$

1. Our salespeople regularly share information within our company about competitors' strategies. $\quad .67$

2. We rapidly respond to competitive actions that threaten us. $\quad .67$

3. Our top managers regularly discuss competitors' strengths and strategies.

4. We target customers where we have an opportunity for competitive advantage. *

Interfunctional coordination: $\mathrm{CR}=.83, \mathrm{AVE}=.50, \mathrm{HSV}=.27$

1. Our top managers from every function regularly visit current and prospective customers.

2. We freely communicate information about our successful and unsuccessful customer experiences across $\quad .81$ all business functions.

3. All of our business functions are integrated in serving the needs of our target market. 76

4. All of our managers understand how everyone in our business can contribute to creating customer $\quad .68$ value.

5. We share resources with other business functions.

Differentiation advantage: $\mathrm{CR}=.90, \mathrm{AVE}=.70, \mathrm{HSV}=.28$

1. Compared to competing products, our products offer superior benefits to customers. .81

2. Our products are unique and nobody but our company can offer them.

3. We take great efforts in building a strong brand name - nobody can easily copy that. $\quad .84$

4. We successfully differentiate ourselves from others through effective advertising and promotion $\quad .77$ campaigns.

Cost advantage: $\mathrm{CR}=.79, \mathrm{AVE}=.52, \mathrm{HSV}=.28$

1. Our manufacturing costs are lower than our competitors'.

2. Our efficient internal operation system has decreased the cost of our products.

3. Our economy of scale enables us to achieve a cost advantage.

4. We have achieved a cost leadership position in the industry.

Institutional advantage: $\mathrm{CR}=.85, \mathrm{AVE}=.59, \mathrm{HSV}=.24$

Compared to our competitors, we have advantages in

1. securing local resources such as land, electricity, and human resources. 63

2. obtaining external funding and financing. $\quad .85$

3. gaining government support and approval.

4. expediting project approval from relevant authorities.

Overall Model Fit: $\chi^{2}(242)=426, p<.001 ; \mathrm{GFI}=.91, \mathrm{CFI}=.92, \mathrm{IFI}=.92 ; \mathrm{RMSEA}=.05$.

Notes: $\mathrm{SFL}=$ standardized factor loading; $\mathrm{CR}=$ composite reliability; $\mathrm{AVE}=$ average variance extracted; $\mathrm{HSV}=$ highest shared variance with other constructs. *Item deleted from further analysis due to low factor loading. 